\title{
マイクロ接合分野における信頼性解析技術の動向
}

\author{
山根 常幸*
}

\section{A Trend of Analysis Technology for Reliability in Microjoining Field}

Tsuneyuki YAMANE*

* 株式会社東レリサーチセンター材料物性研究部（† 520-8567 滋賀県大津市園山3-3-7）

* Materials Characterization Laboratories, Toray Research Center, Inc. (3-3-7 Sonoyama, Otsu-shi, Shiga 520-8567)

\section{1. はじめに}

日本のエレクトロニクス産業は，この 20 年間，高機能 化，高信頼化，小型化，低コスト化の技術開発に支えられ た新たな電子デバイス・部品を組み込んだ電子システム創 成の下, 日本の高度成長を牽引してきた。今後も日本が世 界を先導し続けるには, 生産技術を科学的に探求すること はもちろんのこと, 既存の学問領域, 設計・生産技術など の領域を超えて, エレクトロニクスを取り巻く科学技術, 経営・生産システム, 価值システム, などの広い範囲を取 り込んだグローバルなオプティマイゼーションとそれに基 づくシステムインテグレーションが不可欠になってきてい る。溶接学会マイクロ接合研究委員会は, これら生産技術 に関する最新の研究・開発に関する研究者相互の情報交換 の場をより広くかつ定期的にもち, 生産の科学と技術の進 展を促すことを目的として，「エレクトロニクスにおける マイクロ接合・実装技術シンポジウム（Microjoining and Assembly Technology in Electronics, 略称Mate)」を, 1995年 から年 1 回の頻度で企画開催している。本稿では 2012 年 1月31日, 2月 1 日にパシフィコ横浜にて開催されたMate2012 の概要および本シンポジウムでの信頼性解析技術に関する 最近の発表を事例として当該分野の動向を紹介する。

\section{Mate2012 概要}

溶接学会マイクロ接合研究委員会で作成されたロード マップで掲げた技術目標（高精度・高機能デバイス実装技 術の確立，グリーンデバイス実装技術の確立）をもとに， 「環境エコ社会を支えるエレクトロニクス技術」と題して, 「スマートシティーを支える地域エネルギー管理システム の動向（日立製作所 河野克己氏）」，「普及が進む太陽電 池の研究開発動向の将来展望（富士電機 吉田 隆氏）」, 「エレクトロニクス材料を用いた小型環境振動発電デバイ スの開発（オムロン 正木達明氏）」，3件が講演され，参 加者は約 500 名であった。一般発表は口頭 87 件, ポスター
20 件で，口頭発表のテーマ内訳を図 1 に示す。

優秀な論文に対し，「シンポジウム賞（論文賞，奨励 賞)」を授与しており，今回は優秀論文賞「非接触表面形 状測定計による液状熱硬化性樹脂の化学収縮測定（パナソ ニック 豊田 慶氏, 櫻井大輔氏, 後川和也氏)」など, 計 5 件が選ばれた。

「信頼性」という観点からは, シミュレーション, 検査, 計測といったマクロ的に現象をとらえる発表に加え, 眓2 に示すような各種分光学および表面分析手法を駆使して, 材料特性や界面構造を把握し, 分析 - 解析的に現象のメ力

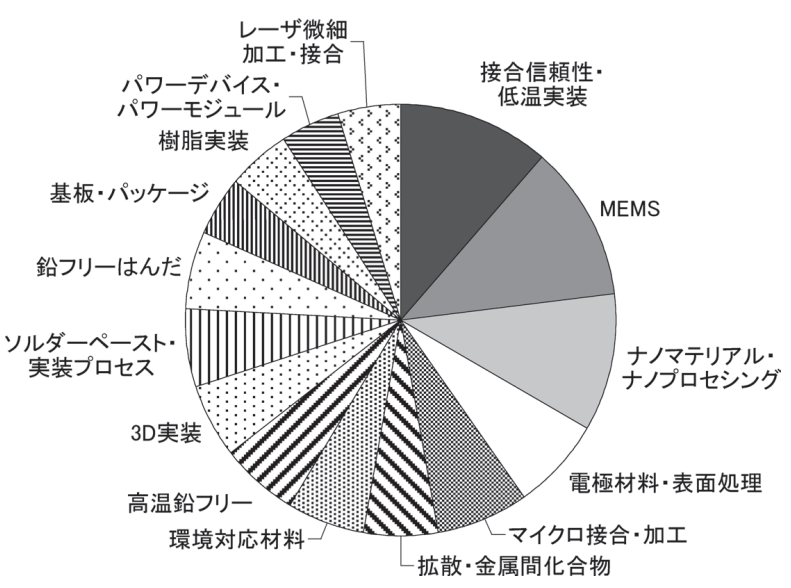

図 1. Mate2012口頭発表（87件）のテーマ内訳

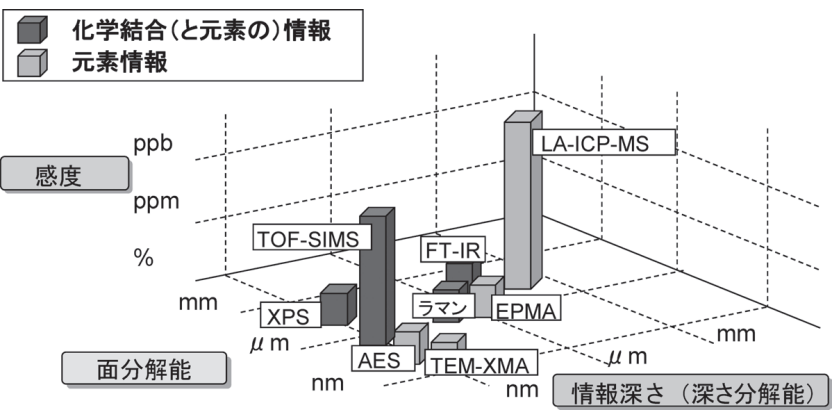

図2、主な分光学および表面分析手法とその特徵 ${ }^{1)}$ 
ニズム解明に結び付けようとする試みが報告されている。 本稿では, BGA (Ball Grid Allay) パッケージ, 太陽電池モ ジュール, ニッケルめっき膜を事例として,これら各種分 析手法による「信頼性解析」の事例を紹介する。

\section{BGAパッヶージはんだ接合部の熱疲労寿命 ${ }^{2)}$}

電子機器の長期信頼性の確保で避けて通れないのが，は んだ接合部の信頼性である。旧来のQFP (Quad Flat Package) 型のパッケージでは, リードフレームとはんだ 材の両方でこのせん断応力を受けとめていたが，BGA型 のパッケージでは，はんだボールがこのせん断応力を吸収 することとなるが，一方接合部でのせん断応力を分散させ るために，パッケージとプリント配線板の間にアンダー フィルを充填されることも多い。以下では，プリント配線 板上に実装された BGAパッケージの冷熱サイクル試験時 の歪み量変化を, 冷熱サイクル試験に歪みゲージを導入す ることで計測，さらに構成材料の劣化状態を評価し，計測 した歪み量変動のメカニズムについて考察した例を紹介す る。

図3に, $-55^{\circ} \mathrm{C} 30 \mathrm{~min} / 125^{\circ} \mathrm{C} 30 \mathrm{~min}$ 条件での冷熱サイク 儿試験を行ったときの所定サイクル時における $-55^{\circ} \mathrm{C} と$ $125^{\circ} \mathrm{C}$ の歪み変化を示す。プリント配線板側（基板側）で は $-55^{\circ} \mathrm{C}$ 側， $125^{\circ} \mathrm{C}$ 側ともに試験数が増加しても歪みの大 きさに変化が認められず，一定の值である。一方，BGA

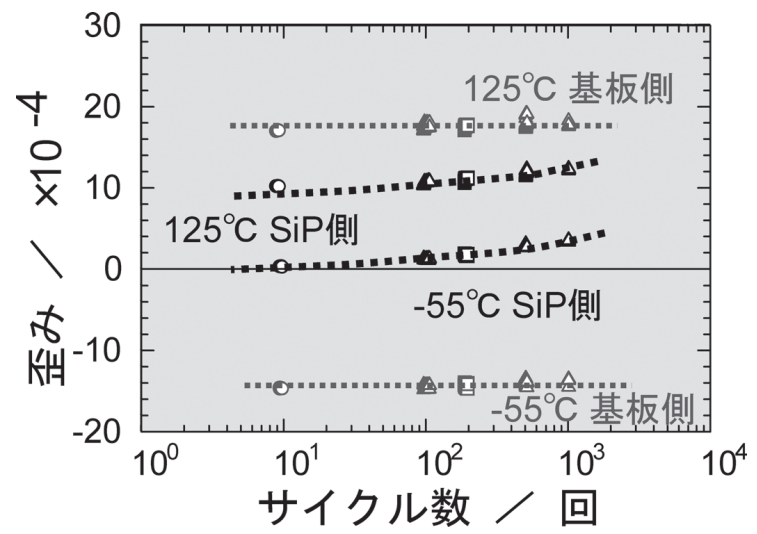

図3. 冷熱サイクル試験 $\left(-55^{\circ} \mathrm{C} 30 \mathrm{~min} / 125^{\circ} \mathrm{C} 30 \mathrm{~min}\right)$ 時 のBGAパッケージの歪み変化

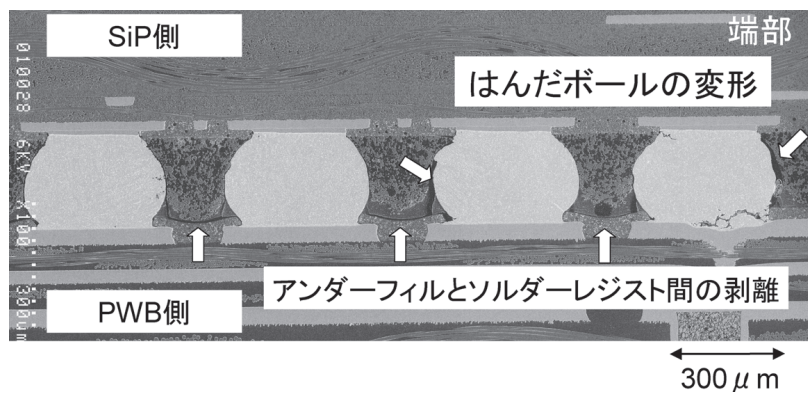

図4.冷熱サイクル試験 1,000回終了後のBGAパッケージ 断面SEM像
パッケージ側（SiP側）ではサイクル数が増加するにつれ， $-55^{\circ} \mathrm{C}$ と $125^{\circ} \mathrm{C}$ のいずれも歪みが正のほうにシフトしてい く。このようなパッケージとプリント配線板の歪みの相対 的な変動（歪みの振幅の増大）は，はんだにかかるせん断 応力が時間とともに増加していくことを示しており，劣化 が加速されていく可能性を示唆している。

図4に冷熱サイクル試験 1,000回終了後のBGA パッケー ジ断面SEM観察結果を示す。最外周のはんだボール端部 （図4中右端）のはんだボールにクラックが観察されてい る。ただし，はんだボールの劣化は全体でなく，最もせん 断応力が集中する端部のみであり，はんだボールの劣化が 歪みゲージで観察された現象を反映しているとは判断でき ない。さらに，断面像を詳細に観察すると，アンダーフィ ルノソルダーレジスト間や，アンダーフィル/はんだボー ル間での剥離か観察され，この現象は広範囲に観察されて いる。これら知見より，アンダーフィルやソルダーレジス トの熱劣化により，剥離が発生した可能性が示唆される。

図5にソルダーレジストの冷熱サイクル試験前後での FT-IR（Fourier Transform-Infrared Spectroscopy，フーリエ

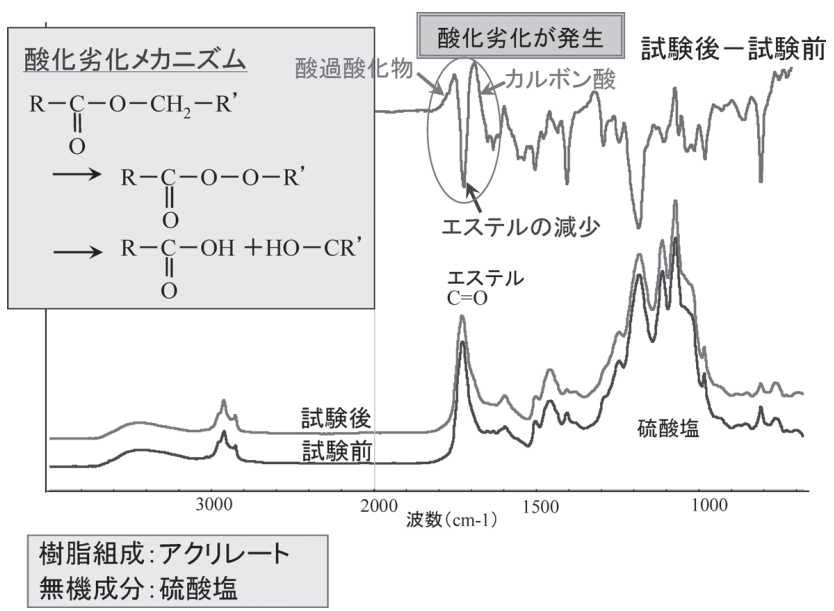

図 5. 冷熱サイクル試験前後のソルダーレジスト赤外スペ
クトル

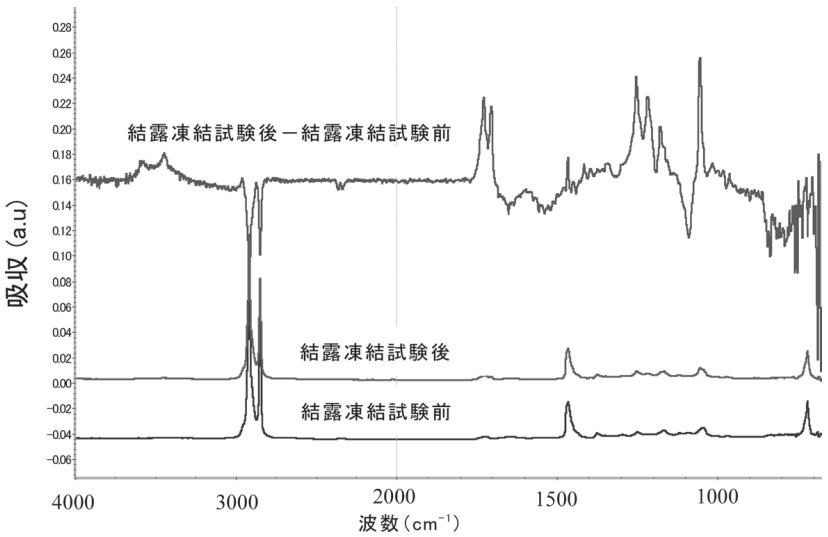

図6. 結露凍結試験前後の ETFE と PEのPE側接合界面近傍 の赤外スペクトルおよび差スペクトル 
変換赤外分光）ATR（Attenuated Total Reflection，全反射） 法による赤外スペクトルを示す。試験後 - 試験前の差ス ペクトルについて， $1,780 \mathrm{~cm}^{-1}$ の酸過酸化物（R-COO-OR）や $1,730 \mathrm{~cm}^{-1}$ のエステルのピークが認められ, 酸化劣 化の存在が確認された。

以上の分析結果から，アンダーフィルやソルダーレジス トの劣化により両者間およびはんだとの剥離が発生し，は んだにせん断応力が集中したと推定される。本応力集中 は，はんだの機械的な強度低下を促進する要素となり，は んだ接合部の信頼性低下の一因となる。このため，パッ ケージ全体の信頼性評価のためには，はんだ部の接合評価 だけでなく，樹脂成分の評価も重要である。

\section{4. 太陽電池モジュールの高分子部材の構造評価 ${ }^{3)}$}

太陽電池モジュールの開発目標として, システムの長寿 命化による生涯発電量を増大させることが掲げられてい る。太陽電池モジュールで最も劣化を受けると考えられる 高分子部材の耐久性向上の評価は，長寿命化および高信頼 性の向上に，非常に重要である。以下では，フィルム型太 陽電池を想定した, ETFE (Ethylene tetrafluoroethylene) と PE (Polyethylene) のフィルムを張り合わせた試料を準備, 結露凍結試験前後品について, 深さ方向に研磨しながら FT-IR ATR法により赤外スペクトルを測定し，接合界面組 成変化および構造解析した例を紹介する。

図6に, 結露凍結試験前後の ETFE と PEのPE側接合界 面近傍の赤外スペクトルおよび，基準ピークを $1,370 \mathrm{~cm}^{-1}$ 付近の $\mathrm{CH}$ 変角（結合角の変化）振動モードとした差スペ クトルを示した。1,300 1,000 $\mathrm{cm}^{-1}$ 付近の吸収帯は, 研 磨時のETFE残存成分である。差スペクトルから, 結露凍 結試験後は，(1) $1,100,800 \mathrm{~cm}^{-1}$ 付近の Si-O結合と推測さ れる吸収帯が減少し，(2) 3,600, 3,400 $\mathrm{cm}^{-1}$ 付近のアミド基 に由来すると考えられる $\mathrm{N}-\mathrm{H}$ 結合扔よび $1,730,1,700 \mathrm{~cm}^{-1}$ 付近のカルボニル基に由来する吸収帯が増加する傾向か認 められた。これら吸収帯はシランカップリング剂などの添 加剤由来と推測され, 結露凍結試験により, 接合界面近傍 の添加剤成分の組成に変化が生じていると考えられる。

図7に深さ方向での組成変化を可視化した検討例とし て，シランカップリング剂由来と考えられる $1,090 \mathrm{~cm}^{-1}$ の 吸収帯強度の深さ方向分布と結露凍結試験回数のイメージ ング像を示す。横軸が深さ方向を示している。試料片の厚 みは試料ごとに完全には一致していないため，試験による 構造変化が少ないと考元られる $1,300 \mathrm{~cm}^{-1}$ の $\mathrm{CH}$ 変角振動 モードに由来する吸収帯強度で規格化している。結露凍結 試験のサイクル数が増加すると，PE層の全体にわたり, ほぼ均一的に $1,090 \mathrm{~cm}^{-1}$ の吸收強度が減少していることが わかる。本結果は，水が透過したことで，層全体にわたり 下記の化学反応による均一な組成変化を生じた可能性を示 唆している。

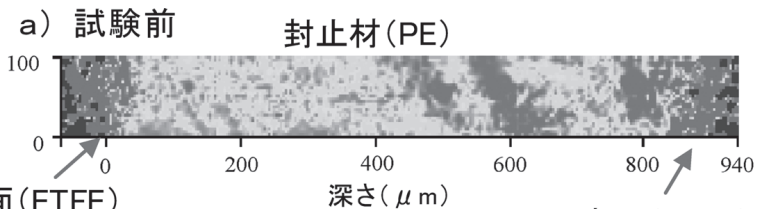

表面 (ETFE)

b) 100 サイクル

裏面 (ETFE)

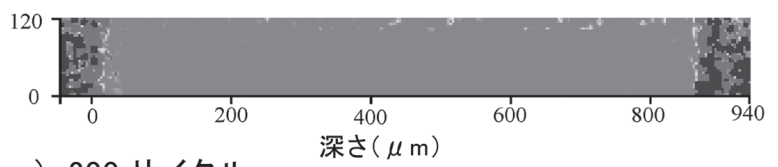

c） 200 サイクル

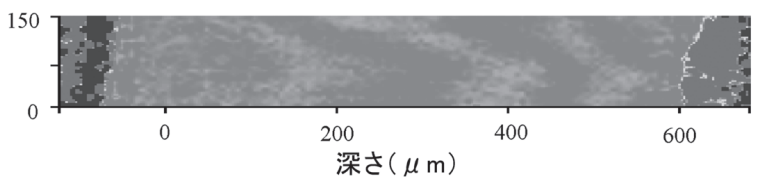

d） 300 サイクル

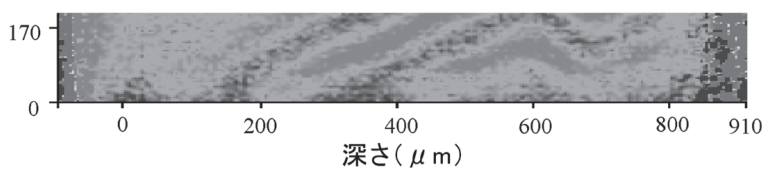

e） 630 サイクル

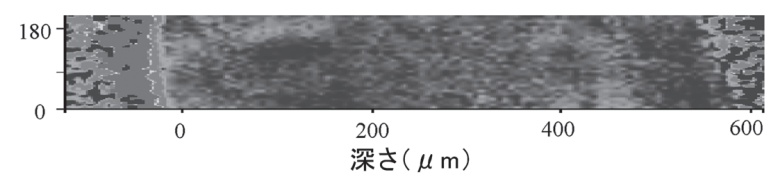

低

高

$1090 \mathrm{~cm}^{-1} / 1300 \mathrm{~cm}^{-1}$ ピーク強度

図7、赤外スペクトル $1,090 \mathrm{~cm}^{-1}$ の吸収帯強度の深さ方向 分布と結露凍結試験回数のイメージング像

$$
\begin{aligned}
& \equiv \mathrm{Si}-\mathrm{O}-\mathrm{R}+\mathrm{H}_{2} \mathrm{O} \rightarrow \equiv \mathrm{Si}-\mathrm{OH}+\mathrm{R}-\mathrm{OH} \\
& \equiv \mathrm{Si}-\mathrm{OH}+\equiv \mathrm{Si}-\mathrm{OH} \rightarrow \mathrm{Si}-\mathrm{O}-\mathrm{Si}-\mathrm{H}_{2} \mathrm{O} \text { (condensation) }
\end{aligned}
$$

ETFE とPEの接合強度に関与しているシランカップリン グ剂は，水の存在により変性し系全体に悪影響を及ぼす可 能性があることがわかる。これらのことから，添加剤の種 類および量を適切に選定することが，システムの耐久性向 上に重要であると考えられる。

\section{5. めっき液の劣化に伴う膜形成への影響評価 ${ }^{4)}$}

ニッケルめっき膜は，拡散障壁機能が大きい，金属間化 合物生成抑制機能が大きい，機械的強度が大きく比較的耐 食性が高いなどの特徵を有する。一方，硬質で割れやす い，酸化するとはんだ濡れ性が劣るなどの欠点も有するた め，それらの特性を考慮した取り扱いが必要である。以下 では，スルファミン酸浴（スルファミン酸ニッケル，八ロ ゲン化ニッケル，ほう酸）に湿潤剤としてラウリル硫酸を 添加した新夜および長期間使用後の劣化液，それぞれを使 用して作製しためっき膜について，TOF-SIMS（Time of Flight-Secondary Ion Mass Spectrometry, 飛行時間型二次 イオン質量分析)，ナノインデンテーションおよびAFM 


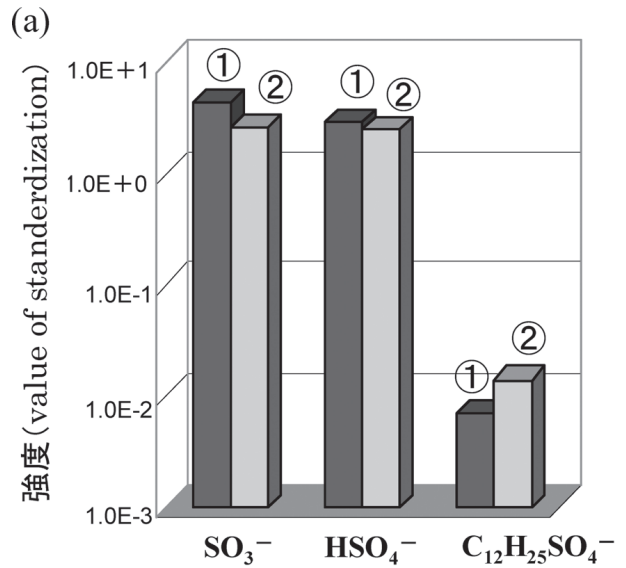

(b)

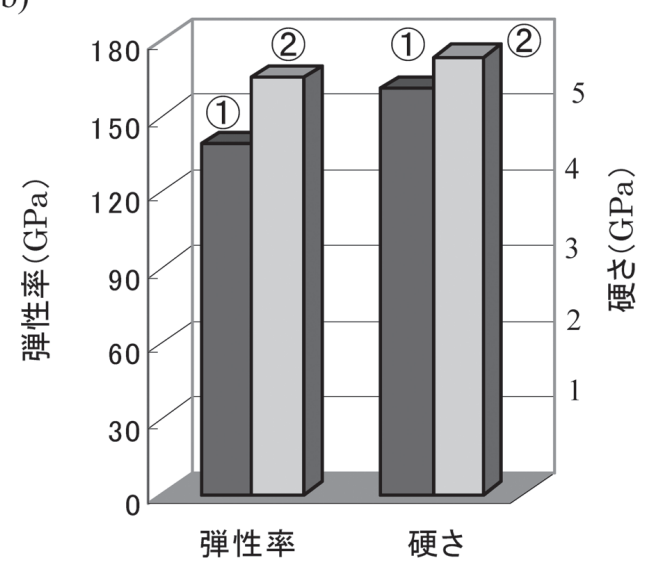

(c)

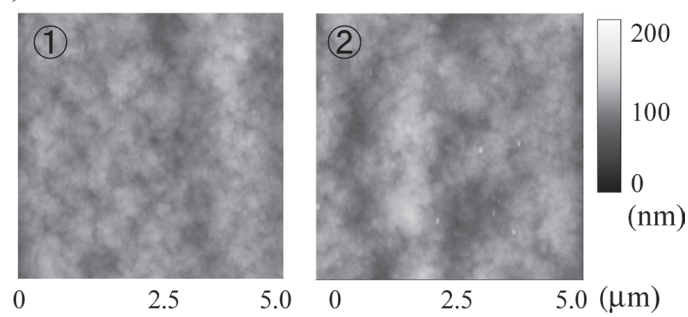

図 8. (1)劣化液, (2)新液を使用して作製したニッケルめっ き膜の (a) TOF-SIMS, (b) ナノインデンテーショ ン, (c) AFM 測定結果

（Atomic Force Microscope, 原子間力顕微鏡）測定で評価 した例を紹介する。

図8(a) は, TOF-SIMS 測定の結果であり, 洗浄工程で除 去しきれなかったと推定される湿潤剤（ラウリル硫酸）由 来の成分が検出され, 劣化液を使用した膜に比べ, 新液を 使用した膜のほうが多くなっている。図8(b) のナノイン デンテーションの結果から, 劣化液を使用した膜のほう が, 弾性率, 硬さともに低い傾向が得られ, また, 図8(c)
の AFM測定の結果から，劣化液を使用した膜のほうが粒 状化し，ミクロな領域で平滑性が悪化していることが予想 された。別途実施しためっき浴のLC/MS/MS 分析（Liquid Chromatography-Tandem Mass Spectrometry, 液体クロマ トグラフィー質量分析）から，新液に比べて劣化液はラウ リル硫酸濃度が低下しており（新液 $8 \mathrm{ppm}$, 劣化液 $3 \mathrm{ppm}$ ), 弾性率の低下および平滑性の悪化は, ラウリル硫酸濃度の 低下による濡れ性の低下や水素気泡の脱離促進効果の減少 が原因であると推定される。上記結果は, めっき浴中の湿 潤剂（ラウリル硫酸）濃度について，厳密な管理の必要性 を示唆している。

\section{6. おわりに}

今後も日本が世界の “ものづくり”を先導し続けるため には,「生産技術の科学的探求」が必須条件であり, その 意味でも, マイクロ接合分野での最新の研究・開発に関す る研究者相互の情報交換の場である Mate, 信頼性評価に おける分析・解析的観点からのアプローチなどの重要性は ますます高まると考えられる。

（2012.6.5-受理）

\section{文献}

1）柴森孝弘：“異物分析,” TRCポスターセッション2010「分 析入門セミナー」テキスト, 2010

2) 伊藤元剛, 的場伸啓, 平野孝行, 三橋和成: “BGAパッ ケージはんだ接合部の熱疲労寿命についての考察,” Mate2011論文集，Vol. 17, pp. 149-152, 2011

3）三橋和成, 宮田洋明, 的場伸啓, 渡邊 猛 : “太陽電池乇 ジュールの高分子部材の構造評価,” Mate2012論文集,

Vol. 18, pp. 301-304, 2012

4）塩路浩隆, 大槻亜紀子, 伊藤元剛, 荻野純一：“めっき液 の劣化に伴う有機添加剂の濃度減少と膜形成への影響評 価,”Mate2011論文集, Vol. 17, pp. 335-336, 2011

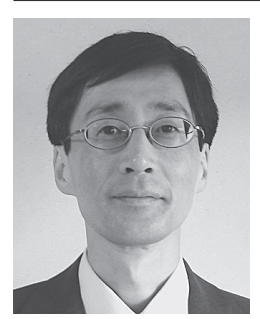

山根常幸（やまねつねゆき）

1986年3月大阪大学大学院理学研究科修士課程修 了。同年 4 月東レ入社。現在, 東レリサーチセン ター材料物性研究部部長。博士（工学）。 